\section{References}

1. Arıkan F, Yıldız Y, Ercan T, Oruç Ö, Akçay S, Yılmaz F, Toptaş T, Tuğlular T. Hydroxychloroquine-associated thrombotic thrombocytopenic purpura. Turk J Hematol 2020;37:302-304.

2. Hindilerden $F$, Yonal-Hindilerden I, Akar E, Kart-Yasar K. CoVID-19 associated autoimmune thrombotic thrombocytopenic purpura: report of a case. Thromb Res 2020;195:136-138.

3. Capecchi M, Mocellin C, Abbruzzese C, Mancini I, Prati D, Peyvandi F. Dramatic presentation of acquired thombotic thrombocytopenic purpura associated with COVID-19. Haematologica 2020;105:e540.
4. Fromm LM. Suspected hydroxychloroquine-induced thrombotic thrombocytopaenic purpura. J Pharm Pract Res 2018;48:72-75.

5. Mar N, Mendoza Ladd A. Acquired thrombotic thrombocytopenic purpura: puzzles, curiosities and conundrums. J Thromb Thrombolysis 2011;31:119121.

6. Naranjo CA, Busto U, Sellers EM, Sandor P, Ruiz I, Roberts EA, Janecek E, Domecq C, Greenblatt DJ. A method for estimating the probability of adverse drug reactions. Clin Pharmacol Ther 1981;30:239-245.

\title{
Antithrombin, COVID-19, and Fresh Frozen Plasma Treatment
} Antitrombin, COVID-19 ve Taze Dondurulmuş Plazma Tedavisi

\author{
(D) Rujitttika Mungmungpuntipantip1, (1) Viroj Wiwanitkit2 \\ 1 Private Academic Consultant, Bangkok, Thailand \\ ${ }^{2}$ Honorary Professor, Dr DY Patil University, Pune, India
}

\section{To the Editor,}

We found the article entitled "Prognostic value of antithrombin levels in COVID-19 patients and impact of fresh frozen plasma treatment: a retrospective study" very interesting [1]. Considering antithrombin (AT) levels and fresh frozen plasma (FFP) in these patients, Anaklı et al. [1] concluded that "AT activity could be used as a prognostic marker for survival and organ failure in COVID-19-associated ARDS patients. AT supplementation therapy with FFP in patients with COVID-19-induced hypercoagulopathy may improve thrombosis prophylaxis and thus have an impact on survival" [1]. Indeed, plasma therapy is a widely discussed alternative option for management of severe coronavirus disease-19 (COVID-19). Some medical scientists have proposed the usefulness of non-convalescent plasma therapy. In a recent report, Bajpai et al. [2] found that the median improvement in $\mathrm{PaO} 2 / \mathrm{FiO}_{2}$ in COVID-19 patients treated with non-convalescent plasma was significantly superior to results of FFP at 48 hours. Additionally, an important consideration for any kind of plasma therapy is the safety. The major consideration is possible pathogenic contamination in plasma [3]. Finally, the exact pathomechanism of COVID-19-related coagulopathy is not well clarified but it is believed to be an immunopathological process [4]. The use of FFP therapy is not direct management for the underlying immunological problem; a more appropriate management might be plasma exchange therapy [5].

Keywords: Antithrombin, COVID-19, Fresh frozen plasma

Anahtar Sözcükler: Antitrombin, COVID-19, Taze dondurulmuş plazma

\section{Ethics}

Informed Consent: Informed consent is not required (no human/animal involvement).

\section{Authorship Contributions}

Concept: R.M., V.W.; Design: R.M., V.W.; Data Collection or Processing: R.M., V.W.; Analysis or Interpretation: R.M., V.W.; Literature Search: R.M., V.W.; Writing: R.M., V.W.

Conflict of Interest: No conflict of interest was declared by the authors.

Financial Disclosure: The authors declared that this study received no financial support.

\section{References}

1. Anaklı I, Ergin Özcan P, Polat Ö, Orhun G, Alay GH, Tuna V, Çeliksoy E, Kılıc M, Mercan M, Ali A, Beşışık S, Esen F. Prognostic value of antithrombin levels in COVID-19 patients and impact of fresh frozen plasma treatment: a retrospective study. Turk J Hematol 2021;38:15-21.

2. Bajpai M, Kumar $S$, Maheshwari $A$, Chhabra $K$, Kale $P$, Gupta $A$, Narayanan A, Gupta E, Trehanpati N, Bihari C, Agarwal R, Gupta K, Gupta UK, Bhardwaj A, Kumar G, Islam M, Singh R, Yadav P, Maiwall R, Sarin SK. Efficacy of convalescent plasma therapy compared to fresh frozen plasma in severely ill COVID-19 patients: a pilot randomized controlled trial. medRxiv Preprints. Available at https://doi.org/10.1101/2020.10.25.20219337.

3. Joob B, Wiwanitkit V. Convalescent plasma and covid-19 treatment. Minerva Med (in press).

4. Iba T, Levy JH, Levi M, Thachil J. Coagulopathy in COVID-19. J Thromb Haemost 2020;18:2103-2109.

5. Tabibi S, Tabibi T, Conic RRZ, Banisaeed N, Streiff MB. Therapeutic plasma exchange: a potential management strategy for critically ill COVID-19 patients. J Intensive Care Med 2020;35:827-835. 
๑Copyright 2021 by Turkish Society of Hematology

Turkish Journal of Hematology, Published by Galenos Publishing House

\section{REPLY FROM THE AUTHORS}

We would like to thank the editor for the opportunity to respond to the issues raised in this letter and to clarify aspects of our methodology in relation to these concerns. In our study, we found that acute antithrombin (AT) deficiency may contribute to both the development of thrombosis and failure to achieve maintained therapeutic anticoagulation in patients with coronavirus disease-2019 (COVID-19). AT supplementation may increase the anticoagulant effect of heparin, so low AT activity levels $(<75 \%)$ were treated with fresh frozen plasma (FFP) in COVID-19-related acute respiratory distress syndrome patients. We observed an increase in AT levels after FFP treatment (from $53 \%$ to $80 \%$ ), and much higher levels were achieved in survivors than nonsurvivors (82\% vs. $76 \%$ ). Thromboembolic events (TEs) were not seen in those patients who had AT activity of $\geq 75 \%$ after FFP treatment and D-dimer levels were significantly reduced after supplementation [1]. In the present letter, the authors mention the usefulness of non-convalescent plasma therapy. However, there is no clear evidence about the usefulness of non-convalescent plasma therapy, the optimal dose, or the time point for this therapy [2]. Studies are limited to small case series, so it is not a drug that is used for a long time and the safety of plasma has not been confirmed. In past studies, there was no significant difference between convalescent plasma and FFP in terms of viral load, cytokine levels, mortality, duration of hospitalization or intensive care stay, and days free of mechanical ventilation [3]. The pathogenic contamination risk is also similar with FFP and finding a donor is not always possible.

A substantial proportion of COVID-19 patients develop thrombotic complications due to the uncontrolled immunothrombotic response. We aimed to prevent TEs and organ dysfunction related to hypercoagulability by using AT supplementation. However, AT concentrates are not available in Turkey, so we treated patients with FFP for AT supplementation. Therapeutic plasma exchange (TPE) has been used for rescue therapy in critically ill patients with COVID-19 who do not respond to conventional therapies [4]. Although used as alternative therapy in COVID-19 patients, extracorporeal therapies may lead to increased cytokine release, thrombosis, and disseminated intravascular coagulation. Studies about extracorporeal membrane oxygenation showed that continuous contact surface between the humoral and cellular components of the blood and the extracorporeal circuit may cause a systemic activation of coagulation and inflammation pathways [5]. Another problem is hemodynamic changes during TPE. Hypotension, arrhythmias, and shock can be seen during TPE. Hypersensitivity and pathogen contamination risk may be higher than in our protocol due to the need for higher FFP volumes for TPE. Also, the efficacy of drugs used for COVID-19 treatment may decrease during TPE because of the removal or dilution of the drugs by TPE. Blood supply difficulties and high costs are other problems related to TPE. It requires skilled staff, special equipment, and extra catheter insertion, so it may not be readily available in many locations. Furthermore, the time frame for TPE is controversial.

Globally, more than 100 million confirmed cases of COVID-19 have been recorded, with more than two million deaths [6]. Various therapeutic agents have been used for COVID-19 patients, all of which remain experimental. More studies need to be done for more effective treatment suggestions.

Illkay Anaklı, Perihan Ergin Özcan, Özlem Polat, Günseli Orhun, Gülçin Hilal Alay, Verda Tuna, Emre Çeliksoy, Mehmet Kılıç, Mutlu Mercan, Achmet Ali, Sevgi Beşışık, Figen Esen

\section{References}

1. Anaklı I, Ergin Özcan P, Polat Ö, Orhun G, Alay GH, Tuna V, Çeliksoy E, Kılıç M, Mercan M, Ali A, Beşışık S, Esen F. Prognostic value of antithrombin levels in COVID-19 patients and impact of fresh frozen plasma treatment: a retrospective study. Turk J Hematol 2021;38:15-21.

2. Balcells $M E$, Rojas $L$, Le Corre $N$, Martínez-Valdebenito C, Ceballos ME, Ferrés $M$, Chang $M$, Vizcaya $C$, Mondaca $S$, Huete $A$, Castro $R$, Sarmiento $M$, Villarroel L, Pizarro A, Ross P, Santander J, Lara B, Ferrada M, Vargas-Salas $S$, Beltrán-Pavez C, Soto-Rifo R, Valiente-Echeverria F, Caglevic C, Mahave M, Selman C, Gazitúa R, Briones JL, Villarroel-Espindola F, Balmaceda C, Espinoza MA, Pereira J, Nervi B. Early versus deferred anti-SARS-CoV-2 convalescent plasma in patients admitted for COVID-19: a randomized phase II clinical trial. PLoS Med 2021;18:e1003415.

3. Bajpai M, Kumar S, Maheshwari A, Chhabra K, kale $P$, Gupta $A$, Narayanan A, Gupta E, Trehanpati N, Bihari C, Agarwal R, Gupta K, Gupta UK, Bhardwaj A, Kumar G, Islam M, Singh R, Yadav P, Maiwall R, Sarin SK. Efficacy of convalescent plasma therapy compared to fresh frozen plasma in severely ill COVID-19 patients: a pilot randomized controlled trial. medRxiv Preprints. Available at https://doi.org/10.1101/2020.10.25.20219337. 
4. Fernandez J, Gratacos-Ginès J, Olivas $P$, Costa $M$, Nieto $S$, Mateo $D$, Sánchez MB, Aguilar F, Bassegoda O, Ruiz P, Caballol B, Pocurull A, Llach J, Mustieles MJ, Cid J, Reverter E, Toapanta ND, Hernández-Tejero M, Martínez JA, Claria J, Fernández C, Mensa J, Arroyo V, Castro P, Lozano M; Covid Clinic Critical Care (CCCC) Group. Plasma exchange: an effective rescue therapy in critically ill patients with coronavirus disease 2019 infection. Crit Care Med 2020;48:e1350-e1355.
5. Von Bahr V, Millar JE, Malfertheiner MV, Ki KK, Passmore MR, Bartnikowski $\mathrm{N}$, Redd MA, Cavaye M, Suen JY, McAuley DF, Fraser JF. Mesenchymal stem cells may ameliorate inflammation in an ex vivo model of extracorporeal membrane oxygenation. Perfusion 2019;34:15-21.

6. World Health Organization. WHO Coronavirus Disease (COVID-19) Dashboard. Geneva, WHO, 2021. Available at https://covid19.who.int/.

\section{Is Sickle Cell Trait Really Innocent?}

Orak Hücre Taşıııcııığı Gerçekten Masum mu?

(1) Mahmut Yeral, (1) Can Boğa

Başkent University Faculty of Medicine, Adana Dr. Turgut Noyan Training and Research Center, Clinic of Hematology, Adana, Turkey

\section{To the Editor,}

Sickle cell trait (SCT) is seen in about $13.6 \%$ of the population living in the Mediterranean region of Turkey [1]. In areas where carriage is common, SCT is considered important for genetic counseling before marriage. Even carriers in widespread regions do not have sufficient information about SCT. Physicians, on the other hand, know that SCT may rarely cause serious complications, but this is often overlooked in daily practice. Is SCT as innocent as it is deemed to be? We explore this further with a clinical case.

After $8 \mathrm{~h}$ of exposure to cold-weather conditions below $0{ }^{\circ} \mathrm{C}$, a 55-year-old man was admitted to the emergency department with severe abdominal pain. On physical examination, there was widespread guarding and rigidity. Laboratory examination results showed that he had a leukocyte level of $14,000 / \mu \mathrm{L}$ (70\% neutrophils), hemoglobin level of $14 \mathrm{~g} / \mathrm{dL}$, and platelet level of $450,000 / \mu \mathrm{L}$. Abdominal tomography images revealed widespread infarct areas in the spleen. Splenectomy had to be performed due to uncontrolled abdominal pain despite narcotic analgesics. At approximately 2 weeks after the splenectomy, the patient was readmitted with severe abdominal pain. Widespread thrombosis was detected in the portal vein. The patient was started on anticoagulant therapy. He lacked personal or family history of thrombosis and was investigated for myeloproliferative diseases and thrombophilia factors. Tests for JAK 2V617F and major BCR/ABL mutations were negative. $A$ bone marrow examination revealed normal cellularity and the absence of fibrosis. Protein $\mathrm{S}$, protein $\mathrm{C}$, and antithrombin III values were within the normal reference ranges; tests for factor $\mathrm{V}$ Leiden, prothrombin gene mutations, and antinuclear antibodies were negative. A flow cytometric study performed with the FLAER method showed that the granulocytes and erythrocytes did not exhibit paroxysmal nocturnal hemoglobinuria. The $\mathrm{Hb}$ electrophoresis results were $38.7 \%$ for $\mathrm{HbS}, 2.9 \%$ for $\mathrm{HbA} 2$, and $58.4 \%$ for $\mathrm{HbA}$. SCT, which is triggered by cold-weather conditions, had started the chain of complications.

In SCT, pathogenesis causing spleen infarction and other complications can triggered by factors such as dehydration, increased viscosity, high altitude, and temperature changes $[2,3]$. Hypoxia in the renal medulla increases sickling, leading to increased cytokines and microthrombi in capillaries and the vasa recta. Microscopic or macroscopic hematuria and abdominal pain develop after ischemia and necrosis. In addition to SCT-associated renal papillary necrosis, chronic kidney disorders and cases of renal medullary carcinoma with poor prognosis and metastasis have been reported $[4,5]$.

There is some information in the literature on athletes and those working in severe conditions who experience exertion-related rhabdomyolysis and sudden death. To prevent serious complications, some countries have implemented national screening programs for newborns, soldiers, and individuals engaged in active sports $[3,6]$. Harmon et al. [7] reported a 37-fold higher risk of exertion death in football players with SCT than in their unaffected peers.

We think that a national newborn-screening program for diagnosing sickle cell disease should be implemented in regions where HbS carriers are common. The aim of the Hemoglobinopathy Control Program implemented in Turkey since 2003 is to provide genetic counseling to $\mathrm{HbS}$ carriers detected via premarital screening, direct them to prenatal diagnosis, and follow children with hemoglobinopathy after birth [8]. It should not be forgotten that SCT is not innocent. Individuals heterozygous for HbS should be informed about clinical problems caused by SCT and recommendations should be made. We believe that adequate information and counseling can minimize complications associated with SCT, such as morbidity and mortality. Screening of this risk group before certain professional or social situations can be life-saving for some carriers. These programs can create ethical and social 